\title{
IN SEARCH OF DIVINITY: PAVING THE PATH FOR SPIRITUAL TOURISM IN GARUT REGENCY, INDONESIA
}

\author{
Aceng Ulumudin, Gugun Geusan Akbar, Ikeu Kania, Rostiena Pasciana, and Pupung \\ Pundensari \\ Faculty of Social and Politics Sciences, Universitas garut \\ Dini T Alamanda \\ Faculty of Economics, Universitas Garut
}

\begin{abstract}
The tourism industry is projected to be the largest foreign exchange earner in Indonesia in 2019, surpassing the oil and gas, coal and palm oil sectors. There is a paradigm shift in tourism from "sun, sand and sea" to "serenity, sustainability and spirituality". The purpose of this study is to examine the conditions and potential of pilgrimage tourism in Garut Regency as part of spiritual tourism destinations. By using a qualitative approach, beside in-dept intervew conducted toward a number of key persons, observation was also carried out to obtain a clear picture of both tangible and intangible elements in the tourist attraction. The results showed that the potential of pilgrimage tourist attractions in Garut Regency were considered very good, even though it had not significantly impact in increasing local revenue (PAD). The strengths and weaknesses of this pilgrimage tourism were discussed comprehensively in this research. The output of this study had a major impact toward the tourism agency of Garut Regency, as a consideration for the tourism potential of Garut which is packed in "Pesona Garut".
\end{abstract}

Keywords: pilgrimage tourism, spiritual tourism destinations, local revenue

\section{Research Background}

A number of tourism variety in Indonesia that potentials to be explored, strengthened and optimized are still hidden. Religious tourism is a distinctive feature of Indonesian civilization. In the period 2010-2015, there has been a rise of 165 percent on religious tourism (Kuswara in Kompas, 2015). Even though, Indonesia Minister of Tourism, Arief Yahya assessed that potential pilgrimage tourism has not been optimally exploited in Indonesia (industri.kontan.co.id, 2015). In the other hand, UNWTO United Nations World Tourism Organization in Kompas (2015) said that around 330 million or approximately $30 \%$ of the total global tourists visit important religious sites around the world, whether based on spiritual motives or cognitive motives. The estimate become concern to the Indonesian government because Indonesia has big opportunity to attract tourist around the world.

Kato \& Progano (2017) state that pilgrimage tours with spiritual-based are an important part of tourism that has expanded meanings including health, fitness and self-improvement motivation.

Indonesia has a very complete and recognized religious-based tourism potential. Not only because of the purpose of religious enlightenment, but it is in demand because there are elements of history, architecture and artistic value (Kavoura, 2013). Religious tourism is part of cultural tourism, where pilgrimage tourism is in it. Pilgrimage tourism as one of the oldest forms of tourism (Štefko et al., 2015). It has 
very complete characteristics as a pilgrimage tourist destination from Islam, Catholicism, Christianity, Hinduism, Buddhism, Confucianism and even a variety of local beliefs which are estimated to reach 245 beliefs.. The population composition based on religious adherents in addition to forming a religious-based tourist segment, will also shape the characteristics of a region-based pilgrimage tourism destination

The potential of pilgrimage tourism which has an Islamic nuance is very much spread throughout the country, although it is often considered as marginal tourism (Štefko et al., 2015). One potential pilgrimage tourist attraction to be seriously developed is the Walisongo site in 8 districts/ cities in the provinces of East Java, Central Java and West Java. Apart from being an Islamic-based cultural heritage, these sites also represent cultural diversity and inter-religious tolerance in Indonesia. The Ministry of Tourism projects that tourist visits at the Walisongo Site in 2019 will be able to reach 18 million domestic tourists or around 15 percent of the target of domestic tourists in 2019 with tourist expenditure per visit averaging IDR 400 thousand or IDR 6.7 trillion a year (Pangaribuan, 2015).

Although it does not have a walisongo tomb, Garut has pilgrimage tourism as a tribute to the spreader of Islam in Garut. There are 4 pilgrimage spots that are popular in Garut Regency, namely the Holy Tomb of Godog, Tomb of Eyang Papak, Tomb of Sunan Cipancar Limbangan, and Ciburuy Bayongbong Site. Latifundia (2016) examined that motivation of pilgrims visiting the sacred tombs because: first, there is a reward for people who make pilgrimages to ancestral tombs (parents), and the saints who spread Islam religious. Second, the vibrations of religious activity; third, to do "tawasul" in the sense of pleading to Allah SWT to fulfill desires such as facilitated provision, facilitated business (trade), promotion etc. And the last, for pilgrims the sacred tomb is a place that has meaning to seek physical and spiritual salvation; sacred place; and believe a very suitable place to perform recitation for pilgrims who prioritize spiritual life.

The increase and development of cultural tourism was emphasized to two aspects namely implementation and object. This achievement depends on cooperation between government agencies and the public, in handling various problems that occur in the development of the pilgrimage tourism in Garut Regency.

Faharani \& Eid (2016) examine about pilgrimage tours with Islamic nuances in Islamic countries in general. The result is that pilgrimage tourism has not been able to generate maximum economic contribution to the country. Several internal and external factors are indicated as the causes. SWOT Analysis is often used as a tool to capture research objects by raising elements of internal (strengths, weaknesses) and external (opportunities and threats). 


\section{Methodology}

\subsection{Object Profile}

a. The Holy Cemetery of Godog

The Godog Cemetery Pilgrimage is located in the village of Godog, Lebak Agung Village, Karangpawitan District, Garut. The location is not far from downtown Garut, pilgrims can visit this place by using two-wheeled vehicles or four-wheeled vehicles. But from the parking lot you have to walk about 20 minutes to get to the destination. There are 9 cemeteries at Godog, one of which is the tomb of Sunan Kian Santang, which is on top of Mount and eight other tombs, or its retainer of Kian Santang is located under the mountain. In addition, there are also heirlooms that are well maintained by the tomb officers

b. Tomb of Eyang Papak

Tomb of Eyang Papak is a graveyard of papak that lives in the middle of the 19th century AD, known as the Sunan Papak. Having a meaning that is noble and has never distinguished human dignity (Papak means: flat, same-Indonesian). Suggestion to the public that the heart is always peaceful. In Sundanese, he advises about "don't Confuse with difficulty". the real name of Eyang papak is Raden Wangsa Muhamad. a fairly famous kyai in Tatar Sunda. The grandparent grave itself is in the Cinunuk village, Wanaraja district, Garut regency.

c. Tomb of Sunan Cipancar Limbangan

Sunan Cipancar is one of the leaders of the ulama and ummara whose role cannot be ignored during the spread of Islam in the interior of West Java, especially in Garut. In addition to exist in the spread of Islam he was also a figure who lowered the regents of Limbangan. In this tomb there are heirlooms that are still very maintained. Heirlooms were always used when making pilgrimages on certain dates and were carried out by the tomb guards.

\section{d. Ciburuy Bayongbong Site}

Another one that is included in the list of pilgrimage tourist attractions in Garut that is visited by many pilgrims as well as a heritage site. The inheritance items are: keris, bande (bell made of bronze), Kujang (Prabu Siliwangi's weapon), "trisula", spear, and ancient writings made of palm leaves and nipah written by Prabu Kian Santang.

\subsection{Method}

This study used a qualitative approach, descriptive and interpretive. Observation was carried out by observing pilgrims (both individuals and groups) while in the cemetery area and surrounding tourism spot. In addition to observations, in-depth interviews both formally and informally were conducted with a number of key persons. The probing technique was also used during the interview to bring up answers related to strengths, weaknesses, opportunities and threat in the pilgrimage tourism object in Garut Regency. 


\subsection{SWOT Analysis}

In general, SWOT analysis can be divided into two categories, namely internal factors and external factors. These internal factors include Strength and Weakness, while external factors include Opportunities and Threats.

Strength is a situation or condition that is a strength that is owned by pilgrimage tourism that can have a positive influence at this time or in the future. This analysis is filled using the following guidelines:

i. What makes this tourism spot is better than other tourism spots in Garut regency?

ii. What uniqueness does Garut pilgrimage tourism have?

Weakness is a situation or condition that is a weakness that is owned by pilgrimage tourism that can give a negative influence at this time or even in the future. This analysis is filled using the following guidelines:

i. What do pilgrims see or feel as a weakness of pilgrimage tourism in Garut regency?

ii. What elements can be improve at pilgrimage tourism?

Opportunities are situations or opportunities outside the company or organization that can provide opportunities to develop in the future. This analysis can be filled using the following guidelines:

i. What opportunities can we see?

ii. What trends are in line with Garut pilgrimage tourism?

Threats are threats that might be faced by a company or organization that can hinder the pace of development of the company or organization. This analysis can be filled using the following guidelines:

i. What obstacles are Garut pilgrimage tourism facing now?

ii. What are the things that are done by Garut pilgrimage tourism's competitors?

iii. Are there changes in government regulations that will threaten the development of Garut pilgrimage tourism?

\section{Result and Discussion}

Pilgrimage tourism area in Garut regency is directed to physical and non physical development. Physical development should be carried out some development activities to improve the area. Some things that must be planned is making the gate of pilgrimage tourism area in Garut regency, permanent parking location, public toilets, road access and signposts to pilgrimage tour in Garut regency.

Non-physical development is aimed at reinforcement local community acceptance of plans to develop pilgrimage tourism area in Garut regency, institutional reinforcement, human resource development as a host providing services to visitors and reinforcement the community to be able to play a role in every stages of 
development from planning, implementation, management, supervision or monitoring and evaluation for development of pilgrimage tourism area in Garut regency. Because basically local community is the owner so they must have a sense of belonging to all the resources contained in its teritory. (Source of Tourism Office of Garut Regency 2015)

In general, tourist attractions in Garut Regency has not been developed optimally by local government, private or by the community. Even though the result of the observation that the tourist area of the pilgrimage tour has very good potential in order to increase the District Own Source Revenue (PAD). Garut Regency has potency of natural tourism, cultural tourism and pilgrimage tour that still original, in other words tourism in Garut regency can be developed as a attraction (object and tourist attraction) regionally and nationally. But in fact that the quality of facilities and infrastructure, access roads to tourist attractions, physical and social environment and also culture in the region is still not optimal.

To describe the results of observations and interviews with some sources that pilgrimage tourism in Garut regency more explicitly used approach and analysis simply as follows::

\section{a) Attractions}

Attraction is magnetism that can invite visitors or tourists to visit the pilgrimage attractions. Tourist attraction that dominant in Garut Regency is a natural potential. At this time Pilgrimage Tours Garut regency has not been fully developed and managed professionally by the local government / private or community (Village / Karangtaruna) as a tourist area that boosts local income and increase District Own Source Revenue (PAD). A pilgrimage attraction as one of the tourism potential in Garut regency has uniqueness that can not be found in other area attractions. This is caused by the historical background of Garut regency and surrounding natural resources.

b) Accessibility

Accessibility is the affordability of a tourist destination or a tourist attraction both physically and socially. Physical accessibility generally consists of roads, bridges and signboards. Social accessibility is local community acceptance. In terms of physical accessibility, especially roads to pilgrimage sites in Garut district from observations and interviews with some visitors results that the condition of facilities and infrastructure to reach the object of pilgrimage is still a lot of obstacles. There are still cavities, turns without any signs and roads are steep enough. This requires continuously maintenance and repairs by the local government of Garut regency.

c) Amenity

Amenity consist of accommodation, catering service (food and beverage), telecommunication services, banking services, guiding and interpretation services etc. At the moment most of the amenitas's components are not yet adequately available in each tourist attraction of pilgrimage in Garut regency. 


\section{d) Activity}

On one side of the activity is an action that can be do by tourists during visit to a tourist destination. At this time tourism activities in Garut Regency is still limited, because the condition of the tourist object has not been well organized and has not get attention from the government and private parties. Though the tourist area has a special attraction that more suitable to accommodate the visitors specific interest associated with the pilgrimage.

On the other hand activity means economic activity that can do by the local community in providing services to visitors / tourists so that activity can empower the local community's economy, at least in an effort to create additional income of local community and become a tourist attraction.

Then the authors analyzed the Characteristics of Tourism Products Macro on Pilgrimage Tour Area in Garut regency. It is necessary to know about the strengths, weaknesses, opportunities, threat faced in the development process. In this regard, the analysis carried out includes an analysis of the available data on the situation and the objective condition of Pilgrimage tourism in Garut Regency and can be analyzed macro for its development through SWOT analysis, as shown on Table 1:

Table 1. SWOT Analysis

\begin{tabular}{|c|c|}
\hline - STRENGTH & $\begin{array}{l}\text { - Pilgrimage Tour in Garut Regency has the } \\
\text { potential of Historical and Cultural } \\
\text { Tourism, such as buildings, sacred places, } \\
\text { historical stories, and traditional } \\
\text { ceremonies. } \\
\text { - A supportive natural environment has an } \\
\text { attractive rural landscape. } \\
\text { - The social environment of the community } \\
\text { is quite supportive as the Pilgrimage } \\
\text { Tourism Object, because its social values } \\
\text { reflect Islamic values. } \\
\text { - The area is still quite wide to be expand. } \\
\text { Has a rich traditional social cultural } \\
\text { potential, whether arts, ceremonies, } \\
\text { traditions, unique customs. }\end{array}$ \\
\hline WEAKNESS & $\begin{array}{l}\text { Terraced topography should get attention } \\
\text { in the management and development of } \\
\text { the area as it may cause environmental } \\
\text { degradation. } \\
\text { environmental arrangement that is less } \\
\text { attention to the zoning system causes } \\
\text { disorder organized of Pilgrimage Tour's } \\
\text { Object in Garut regency. }\end{array}$ \\
\hline
\end{tabular}




\begin{tabular}{|c|c|}
\hline & $\begin{array}{l}\text { - tourist information facility is not complete } \\
\text { yet, such as the unavailability of story } \\
\text { telling that causes tourists difficult to get } \\
\text { comprehensive information about the } \\
\text { Object of Pilgrimage Tour in Garut } \\
\text { regency. } \\
\text { - the Pilgrimage Tour's Location in Garut } \\
\text { regency that blends with the settlement } \\
\text { makes this tourist attraction feels narrow. } \\
\text { - Inadequate Facilities makes the } \\
\text { Pilgrimage tour's Object in Garut district } \\
\text { difficult to visit by tourists in large } \\
\text { numbers (using large buses). } \\
\text { - Limited facilities and security forces, } \\
\text { especially during the high season. } \\
\text { the lack of Supporting facilities and } \\
\text { infrastructure make the visitor comfort } \\
\text { level decrease } \\
\text { the management that has not been } \\
\text { optimal make Pilgrimage Tour's Object in } \\
\text { Garut regency unorganized. }\end{array}$ \\
\hline OPPORTUNITY & $\begin{array}{l}\text { Pilgrimage-based tourism development } \\
\text { opportunities in Garut regency is quite } \\
\text { big, because the growing tradition of } \\
\text { pilgrimage tourism among Muslims. } \\
\text { - the opportunity of historical and cultural } \\
\text { tourism products development is quite } \\
\text { open considering the number of folklore } \\
\text { associated with religious leaders and also } \\
\text { heritage objects. } \\
\text { - Educational tourism development } \\
\text { opportunities, such as research on } \\
\text { folklore, traditional architecture, and } \\
\text { community traditions. } \\
\text { Opportunities to develop cultural } \\
\text { attractions by utilizing the arts and } \\
\text { traditions of the surrounding community. }\end{array}$ \\
\hline THREAT & $\begin{array}{l}\text { - } \quad \text { low quality and capability of tour manajer } \\
\text { - Community participation does not reflect } \\
\text { support for object development. } \\
\text { - Lack of coordination between } \\
\text { Government / private stakeholders in the }\end{array}$ \\
\hline
\end{tabular}




\begin{tabular}{|l|l|}
\hline & $\begin{array}{l}\text { management of tourist attractions. } \\
\text { - The existence of similar tourism object } \\
\text { that more accessible locations in the West } \\
\text { Java such as the Tomb of Sunan Gunung } \\
\text { Djati, Tomb of Sheikh Abdul Muhyi } \\
\text { Pamijahan which visitors are more } \\
\text { interested to the location because of better } \\
\text { access and facilities. }\end{array}$ \\
\hline
\end{tabular}

\section{Conclusion}

Based on the results of research and discussion, it can be concluded as follows:

1. Pilgrimage Tour Object Potential in Garut Regency is quite significant because the potential of Historical and Cultural Tourism, such as buildings, sacred places, historical stories, and traditional ceremonies and also a good natural environment that will support the District Own Source Revenue (PAD).

2. Nevertheless there are still some obstacles in the management of Pilgrimage Tour Object in Garut regency, such as:

a) Nonoptimal facilities and infrastructure availablity in the Pilgrimage Tour Object in Garut regency.

b) A public transport access and private transportation is quite difficult to reach the Pilgrimage Tourism Object in Garut regency.

c) Quality of service that has not been optimal to visitor attractions.

3. Information about the object of Pilgrimage Tour in Garut regency cannot be obtained easily from various sources.

Based on the results of research, the suggestions that can be donated from researchers are as follows:

1. The need to re-arrange the environment of Pilgrimage Tourism Object in Garut regency by observing the zoning system (zonation) that is around the Object of Pilgrimage Tour in Garut regency.

2. The need to provide tourist information facilities such as story telling for tourists so that they can be thorough information about Pilgrimage Tourism Object in Garut regency.

3. The need to improve access road to the location so that visitors are easy to visit the location of Tourism Object Pilgrimage in Garut regency.

4. The availability of various supporting facilities such as extensive and secure permanent parking lot for visitors vehicles, toilets etc.

5. The need for better management for each Pilgrimage Tourism Object in Garut regency. 


\section{Acknowledgment}

The results of the research carried out we would like to thank the Ministry of Research and Technology of the Ministry of Education and Regional Government, the officers of the pilgrimage tourist sites and colleagues in the Faculty of Social and Political Sciences of the University of Garut who have helped in the completion of this study.

\section{References}

Andriwidjaja, R. (2007). Pembangunan Pariwisata. Bappeda Jawa Barat.

Devas, N. B. (1989). Keuangan Pemerintahan Daerah di Indonesia. Jakarta: UI-Perss.

Easton, D. (1969). Public Policy. Jogjakarta: Gajah Mada Perss.

Farahani, H. Z., \& Eid, R. (2016). Muslim world: A study of tourism \& pilgrimage among OIC Member States. Tourism Management Perspectives, 19(B), 144-149.

Gafur, J. D. (2008). Analisis Kontribusi Sektor Pariwisata terhadap Pendapatan Asli Daerah Kota Bitung. Tesis, 37-42.

Gamel, S. S. (2008). Kebijakan dan Kebijakan Emha Syeh Harto, Persiden Seribu Satu Mesjid. Siduarjo: Garisi.

industri.kontan.co.id. (2015, 10 16). Menpar dorong pengembangan destinasi wisata ziarah. Retrieved from industri.kontan.co.id: https://industri.kontan.co.id/news/menpar-dorong-pengembangan-destinasiwisata-ziarah

Kato, K., \& Progano, R. N. (2017). Spiritual (walking) tourism as a foundation for sustainable destination development: Kumano-kodo pilgrimage, Wakayama, Japan. Tourism Management Perspectives, 24, 243-251.

Kavoura, A. (2013). Politics of heritage promotion: branding the identity of the Greek state. Tourism, Culture and Communication, 12, 69-83.

Kompas. (2015, 11 22). Wisata Religi Semakin Ngetren. Retrieved from travel.kompas.com:

https://travel.kompas.com/read/2015/11/22/163800927/Wisata.Religi.Semak in.Ngetren

Latifundia, E. (2016). Unsur Religi pada Makam-makam Kuna Islam di Kawasan Garut. Jurnal Lektur Keagamaan, 14(2). doi:10.31291/jlk.v14i2.509

Lundbreg, E. D. (1997). Ekonomi Pariwisata. Jakarta: PT Gramedia Pustaka Utama. 
Moleong, L. J. (2005). Metodologi Penelitian Kualitatif (Edisi Revisi). Bandung: PT. Remaja Rosdakarya.

Pangaribuan, M. (2015, 10 16). Menpar: Potensi Wisata Religi Walisongo Rp 3,6 Triliun. Retrieved from satuharapan.com: http://www.satuharapan.com/readdetail/read/menpar-potensi-wisata-religi-walisongo-rp-36-triliun

Purwadi, d. (2006). Jejak Para Wali dan Ziarah Pritual. Jakarta: Kompas.

Rifai, F. K. (2012). Strategi Pengembangan Potensi Wisata untuk Meningkatkan Pendapatan Asli Daerah (Studi Pada Dinas Kebudayaan, Pariwisata, Pemuda dan Olahraga Kabupaten Klaten. Ampta Jurnal,, 28-35.

Santoso, B. (1995). Retribusi Pasar sebagai Pendapatan Asli Daerah, Studi Kasus Pasar Kabupaten di Sleman. Prisma No. 4 tahun XXIV, 19-35.

Schwandt, T. A. (2000). Three Epistemological Stances for Qualitative Inquiry dalam Handbook of Qualitative Research, Scond Edition. Sage Publications.

Štefko, R., Királ'ová, A., \& Mudrík, M. (2015). Strategic Marketing Communication in Pilgrimage Tourism. Procedia - Social and Behavioral Sciences, 175(12), 423-430.

Syafiie, I. K. (2009). Pengantar Ilmu Pariwisata. Bandung: Mandar Maju.

Thalia, Z. (2015). Pengembangan Wisata Budaya Berbasis Wisata Ziarah sebagai Wisata Minat Khusus di Kabupaten Karanganyar. Publikasiilmiah.usm.ac.id, 42:46.

Yoeti, O. (2003). Pengantar Ilmu Pariwisata. Bandung: Angkasa.

\section{Newspaper Article}

http://www.indosiar.com/v2/culture/culture_read.htm?id=28422\&tp=teropong, edisi 19 Juli 2005, dalam artikel

\section{Journal Article on Website}

http://www.indosiar.com/v2/culture/culture_read.htm?id=28422\&tp=teropong, edisi 19 Juli 2005, dalam artikel 